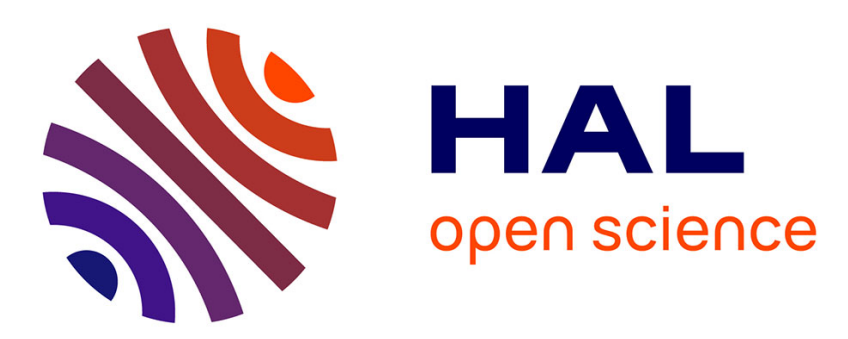

\title{
Estimating metabolizable energy content (ME) from the digestible proximate analysis, TDN and DE of different classes of feedstuffs for cattle and sheep
}

Mf Wardeh, Le Harris, Lc Kearl

\section{To cite this version:}

Mf Wardeh, Le Harris, Lc Kearl. Estimating metabolizable energy content (ME) from the digestible proximate analysis, TDN and DE of different classes of feedstuffs for cattle and sheep. Annales de zootechnie, 1995, 44 (Suppl1), pp.276-276. hal-00889435

\section{HAL Id: hal-00889435 \\ https://hal.science/hal-00889435}

Submitted on 1 Jan 1995

HAL is a multi-disciplinary open access archive for the deposit and dissemination of scientific research documents, whether they are published or not. The documents may come from teaching and research institutions in France or abroad, or from public or private research centers.
L'archive ouverte pluridisciplinaire HAL, est destinée au dépôt et à la diffusion de documents scientifiques de niveau recherche, publiés ou non, émanant des établissements d'enseignement et de recherche français ou étrangers, des laboratoires publics ou privés. 


\title{
Estimating metabolizable energy content (ME) from the digestible proximate analysis, TDN and DE of different classes of feedstuffs for cattle and sheep
}

\author{
MF Wardeh 1, LE Harris 2, LC Kearl 2 \\ 'Department of Studies of Animal Wealth, ACSAD, PO Box 2440, Damascus, Syrian Arab Republic; \\ 2International Feedstuffs Institute Utah State University, Logan, USA
}

The objective of this study was to develop improved statistical models to predict the ME content of feeds for ruminants. Data on proximate nutrient contents, digestibility and energy utilization of feedstuffs were obtained from the Feed Information Databank (International Feedstuffs Institute, Utah State University). Feedstuffs of the databank were divided into five classes: (1) dry forages and roughages ; (2) pasture, range plants and forages fed green; (3) silages ; (4) energy feeds ; (5) protein supplements. Both simple and multiple linear regression models were developed to estimate ME from TDN, DE, and from the combined digestible proximate components. The Statistical Package For The Social Sciences (SPSS; Nie et al, 1975, Mac Graw-Hill, New York) was used to develop models to predict ME. The multivariate data collection regression (MDCRI Hurst, 1979, Utah State Univ, Ohio) program was also used to make data transformation and generate dummy variables (qualitative data). A coordinated program, stepwise multiple regression upward (SMRU) was used to generate multiple linear regression equations.

Data from cattle and sheep showed ME to be highly predictable, with multiple regression equations developed with the digestible proximate nutrients $\left(\mathrm{R}^{2}=0.73\right.$ to 0.99 ; $\mathrm{RSD}=0.04$ to $0.07 \mathrm{Mcal} / \mathrm{kg}$ ) of the various classes of feedstuffs. These equations are similar to those of Nehring and Haenlein (1973, $J$ Anim Sci, 36, 949) and Van Es (1978, Livest Prod Sci, 5, 331), except that their equations were developed with combined data from all classes of feeds and a regression constant was not calculated.

ME was highly correlated $\left(R^{2}=0.71\right.$ to 0.95$)$ with the TDN content of different classes of feedstuffs for cattle and sheep, except that ME had a low correlation with TDN of dry forages and roughages for cattle $\left(R^{2}=0.29\right.$; RSD $=0.11 \mathrm{Mcal} / \mathrm{kg}$ ), partly due to the narrowness of the range of the relevant data. Data for sheep, however showed high correlations between ME and TDN values of the same class feed $\left(\mathrm{R}^{2}=0.90 ; \mathrm{RSD}=0.07\right.$ $\mathrm{Mcal} / \mathrm{kg}$ ) and of pasture, range plants, and forages fed green $\left(R^{2}=0.71\right)$. Both cattle and sheep data produced high correlations between ME and TDN values of silages $\left(R^{2}=0.78\right.$ and $0.90 ; R S D=0.07 \mathrm{Mcal} / \mathrm{kg}$, respectively). ME could be estimated from TDN for energy feeds for cattle $\left(R^{2}=0.89\right) M E$ could also be estimated from DE with reasonable accuracy for dry forages and roughages for cattle $\left(R^{2}=0.87\right)$, sheep $\left(R^{2}=0.93\right.$; $\mathrm{RSD}=0.05$ and $0.06 \mathrm{Mcal} / \mathrm{kg}$, respectively), and for silages $\left(R^{2}=0.92\right.$ and 0.94 ; $\mathrm{RSD}=0.04$ and $0.06 \mathrm{Mcal} / \mathrm{kg}$, respectively).

A less reliable estimate of ME could be obtained with pasture, range plants, and forages fed fresh to sheep ( $R^{2}=0.77$; $\mathrm{RSD}=0.21 \mathrm{Mcal} / \mathrm{kg}$ ). The ME of energy feeds could be estimated with the experimentally determined DE for cattle $\left(\mathrm{R}^{2}=0.66\right.$; RSD $=0.18 \mathrm{Mcal} / \mathrm{kg}$ ) but insufficient data were available for sheep. 